\title{
Original
}

\section{Changes in Coagulative and Fibrinolytic Activities in Rats with Acute Diabetes Induced by Streptozotocin}

\author{
Masako OkaZaki, Hideharu SaKamoto, Hironori Katoh, \\ Mayumi TsuJI and Katsuji OguchI
}

\begin{abstract}
Changes in coagulation and fibrinolysis were studied in SpragueDawley rats with acute diabetes induced by a single intravenous injection of $65 \mathrm{mg} / \mathrm{kg}$ or $45 \mathrm{mg} / \mathrm{kg}$ of streptozotocin (STZ). At 2,24 and $48 \mathrm{hr}$ after $65 \mathrm{mg} / \mathrm{kg}$ injection and $144 \mathrm{hr}$ after $45 \mathrm{mg} / \mathrm{kg}$ injection, plasma glucose was drastically increased. Suppression of body weight gain and an increase in food and water intake were observed in the $45 \mathrm{mg} / \mathrm{kg}$ STZ-treated rats. Plasma lipids increased 24 and $48 \mathrm{hr}$ after $65 \mathrm{mg} / \mathrm{kg}$ of STZ treatment, but only triglyceride increased $144 \mathrm{hr}$ after $45 \mathrm{mg} / \mathrm{kg}$ injection. Partial thromboplastin time (PTT) was significantly shortened $48 \mathrm{hr}$ after $65 \mathrm{mg} / \mathrm{kg}$ and $144 \mathrm{hr}$ after $45 \mathrm{mg} / \mathrm{kg}$. Antithrombin III activity (ATIII) increased significantly $144 \mathrm{hr}$ after $45 \mathrm{mg} / \mathrm{kg}$. Activity of factor XIII decreased $24 \mathrm{hr}$ after $65 \mathrm{mg} / \mathrm{kg}$ injection. Neither 65 $\mathrm{mg} / \mathrm{kg}$ nor $45 \mathrm{mg} / \mathrm{kg}$ induced changes in the fibrinogen level or fibrinolytic activity. A remarkable increase in plasma glucose was interrelated with shortening of PTT and increased ATIII activity in STZ-treated rats. These results demonstrated enhancement of intrinsic coagulation in rats with acute diabetes induced by STZ.
\end{abstract}

Key words: streptozotocin, diabetes, coagulation, fibrinolysis, rat

\section{Introduction}

Diabetes mellitus is a chronic disorder characterized by a rise of the glucose level in blood. The risk of atherosclerotic complications is markedly increased in diabetes mellitus because of their vascular complications ${ }^{11}$. Several studies in the last decade showed that adult diabetic patients frequently have atherosclerotic diseases such as myocardial infarction and stroke, and that they have increased platelet aggregation, particularly those with retinopathy and advanced vascular changes ${ }^{2 .: 3)}$. Recently, the elevation of plasma concentrations of thromboxane $\mathbf{B}_{2}$, Factor VIII, von Willebrand factor-related antigen, and ristocetin cofactor indicating a hypercoagulable state was demonstrated in diabetes mellitus ${ }^{4)}$. However, there are few reports which discuss the changes in coagulative and fibrinolytic activity in diabetic animals as experimental models. To know the relation between the blood coagulative system and diabetic condition is important for revealing the mechanisms of atherosclerotic development. To examine the coagulative and fibrinolytic activities in diabetes mellitus, we used streptozotocin (STZ)-treated rats. Because different doses of STZ, which is derived from Streptomyces achromogenes ${ }^{\text {i) }}$, selectively destroy the pancreatic B-cell, it is possible to produce Department of Pharmacology, Showa University School of Medicine, 1-5-8 Hatanodai, Shinagawa-ku, Tokyo 142, Japan. 
graded states of diabetes in rats $^{6}$. We have already reported increased coagulative activity and indirect enhancement of fibrinolytic activity in hyperlipidemic rats ${ }^{i}$. The purpose of the present study was to investigate the changes in the coagulation and fibrinolysis and plasma lipid contents in STZ-treated rats, and discuss the relation between STZ-induced acute diabetes and atherosclerosis.

\section{Materials and Methods}

\section{Experimental animals}

Male Sprague-Dawley rats, 6 weeks old at the start of the experiment, were fed a stock diet (MF, Oriental Yeast Co., Ltd., Japan) and tap water ad lib. under standard laboratory conditions $\left(21 \pm 2^{\circ} \mathrm{C}, 55 \pm 15 \%\right.$ humidity). In preliminary experiments to determine the dcsage of STZ, $65 \mathrm{mg} / \mathrm{kg}$ of STZ induced an increase in the mortality rate $72 \mathrm{hr}$ after injection. To determine the effect of the sustained high plasma levels of glucose, rats treated with $45 \mathrm{mg} / \mathrm{kg}$ of STZ were also examined. Each animal was housed individually for at least 5 days prior to the experiment.

\section{Experimental procedures}

Diabetes was induced by a single intravenous injection of streptozotocin (STZ: 2-deoxy2-(methylnitrosoamino)-carbonyl-amino-D-glucopyranose), purchased from Sigma Chemical Co. (St. Lois. MO, U.S.A.). Each animal was fasted for $18 \mathrm{hr}$ after prefeeding for 5 days, and then received STZ $(65 \mathrm{mg} / \mathrm{kg}$ or $45 \mathrm{mg} / \mathrm{kg}$ in $0.05 \mathrm{M}$ citrate buffer, $\mathrm{pH} \mathrm{4.5)} \mathrm{via} \mathrm{tail}$ vein injection. Control rats were injected intravenously with a corresponding volume of citrate buffer. In acute diabetes induced by $65 \mathrm{mg} / \mathrm{kg}$ dose, we sacrificed rats for examination at 2, 7, 24 and $48 \mathrm{hr}$ after injection. Treated rats were fasted until sacrifice and control rats were fasted for corresponding periods. In acute diabetes induced by $45 \mathrm{mg} / \mathrm{kg} \mathrm{STZ}$, the animals were sacrificed $144 \mathrm{hr}$ after treatment. In rats treated with $45 \mathrm{mg} / \mathrm{kg} \mathrm{STZ}$ and allowed free access to food and water, changes in daily body weight and intake of food and water were examined for 5 days.

Blood collection and preparation

Blood specimens were taken from the inferior vena cava with a plastic syringe and a siliconcoated needle under pentobarbital anesthesia $(40 \mathrm{mg} / \mathrm{kg}$, i.p.). Whole blood from rats was mixed $3.2 \%$ sodium citrate solution in a volume ratio of nine to one, and then centrifuged at 3000 r.p.m. for $15 \mathrm{~min}$ at $4{ }^{\circ} \mathrm{C}$. The supernatant was used for specimens as citrated plasma.

\section{Blood examination}

Ethylenediaminetetraacetic acid disodium salt-treated blood was analyzed for platelet, white blood cell (WBC) and red blood cell (RBC) counts and the values of hematocrit (Ht) and hemoglobin $(\mathrm{Hb})$ using automated equipment (Coulter Counter, S-plus size distribution, Coulter Electronics, Inc., Japan).

Plasma glucose and plasma lipid levels

Plasma glucose levels were determined using commercially available diagnostic kits (Glucose Test Wako: Wako Pure Chemical Ind., Ltd., Japan). Total plasma lipid was determined by the method of Bragdon ${ }^{8)}$. Total cholesterol was determined by colorimetry (Cholesterol-B Test). Phospholipid and triglyceride contents were determined enzymatically (Phospholipid-B Test and Triglyceride-G Test, respectively). Nonesterified fatty acid (NEFA) was determined by the method of Duncombe"'). These assays were performed using commercial kits (Wako Pure Chemical Ind., Ltd., Japan). 
Assay of coagulative and fibrinolytic activities

1. Prothrombin time (PT) and partial thromboplastin time (PTT). PT was measured using Simplastin (Warnar-Lambert Co., Ltd.) in a modified one-stage method. Simplastin contains a tissue thromboplastin reagent (rabbit brain and lung), $\mathrm{CaCl}_{2}$ and $\mathrm{NaCl}$. PTT was measured using Platelin (Warnar-Lambert Co., Ltd.) by the method of Langdell et al. ${ }^{10)}$. Platelin contains a plasma thromboplastin reagent (rabbit brain phospholipid) and $\mathrm{NaCl}$. Measurement of PT and PTT was conducted using Clot-Digitim TE-20 (Erma Optical Works, Ltd., Japan).

2. Fibrinogen level. Fibrinogen level was measured by the method of Tomikawa et al. ${ }^{111}$. Citrated plasma was mixed with $\mathrm{CaCl}_{2}$ and tranexamic acid (Sigma Chemical Co. St. Lois. MO, U.S.A.) and the mixture was incubated at $37^{\circ} \mathrm{C}$. After removal of the non-clottable proteins from the diluted plasma clot by centrifugation, the protein content of the fibrin precipitate was determined by the method of Lowry et al. ${ }^{12)}$.

3. Factor XIII. We followed the conventional method using a commercial kit (F. XIII, Iatron Laboratories, Inc., Japan). The activities of factor XIII were determined on the basis of the intensity of fluorescence from the dansylcadaverine complex by a fluorescence spectrofluorometer (Hitachi 650-10M Fluorescence spectrophotometer, Japan).

4. Antithrombin III (ATIII). ATIII activity was determined by synthetic chromogenic substrates (Tosyl-Gly-Pro-Arg-pNa: Chromolate ATIII, Iatron Laboratories, Inc., Japan).

5. Plasminogen (PLG) and $\alpha_{2}$-plasmin inhibitor. PLG assay was conducted by the chromogenic method using S-2251 as a substrate (Kabi Diagnostica, Daiichi Chemical Pharmacy Co., Ltd. Japan). We used urokinase (Mochida Pharmaceutical Co., Ltd. Japan) as the PLG activator because the PLG of the rat and mouse is activated by urokinase but not by streptokinase $^{13)}$. Activity of $\alpha_{2}$-PI was determined by a method using the synthetic chromogenic substrate, S-2251, the same substrate used for PLG assay.

Statistical analysis

Results were expressed as mean \pm S.D. of 7 to 9 rats per group. Statistical significance was evaluated using Student's $t$-test.

\section{Results}

\section{Body weight, and food and water intake}

Figure 1 shows daily body weight and intake of food and water after STZ injection (45 $\mathrm{mg} / \mathrm{kg}$ ) in rats. There was no increase in body weight gain in STZ-treated rats, although that of control rats increased naturally. The amount of food consumption increased significantly on the 4th and 5th days, whereas water intake increased drastically day by day and the amount of water consumption on the 5 th day was about 8 times that of control rats that received citrate buffer injection alone.

Plasma glucose and blood examination

Figure 2 shows changes in plasma glucose levels after STZ injection in rats. After injection of $65 \mathrm{mg} / \mathrm{kg} \mathrm{STZ}$, rats could not eat anything due to STZ toxicity, although they were allowed free access to food and water. In this acute diabetes, plasma glucose levels were increased at 2,24 and $48 \mathrm{hr}$, but were decreased significantly at $7 \mathrm{hr}$. However, in control rats, there were no apparent changes in plasma glucose levels due to the fasting. At $144 \mathrm{hr}$ after STZ injection of $45 \mathrm{mg} / \mathrm{kg}$ in rats which were allowed free access to food and water after injection, plasma glucose levels increased to about 2.2 times that of the 


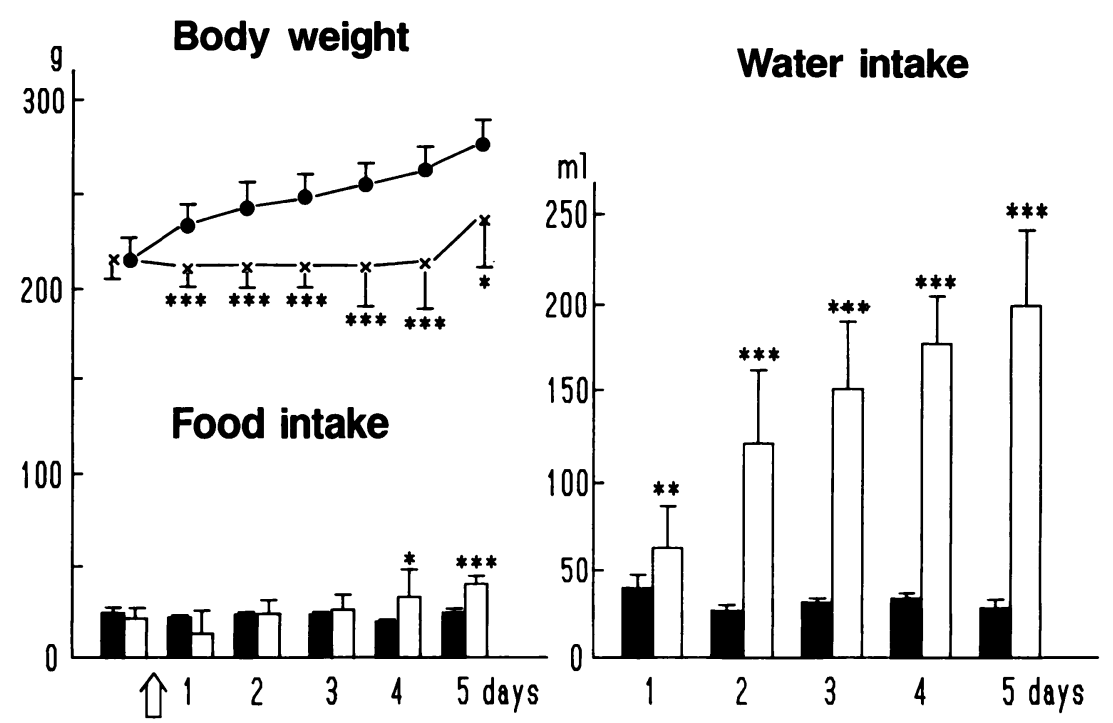

Fig. 1. Changes in body weight and intake of food and water after intravenous injection of $45 \mathrm{mg} / \mathrm{kg}$ streptozotocin (STZ) in rats.

Each animal was fasted for $18 \mathrm{hr}$ after prefeeding for 5 day, and then received STZ ( $\times-\times$ and $\square: 45 \mathrm{mg} / \mathrm{kg}$ in $0.05 \mathrm{M}$ citrate buffer, $\mathrm{pH} 4.5$ : arrow). Control rats (- and received a corresponding volume of $0.05 \mathrm{M}$ citrate buffer. Body weights and food intake amounts were shown in $\mathrm{g}$ and water intake amounts were shown in $\mathrm{ml}$. Each point or column is mean \pm S.D. of 6 or 7 rats. $*$, **, *** significant difference from the citrate buffer control value with $\mathrm{p}<0.05, \mathrm{p}<0.01, \mathrm{p}<0.001$, respectively.

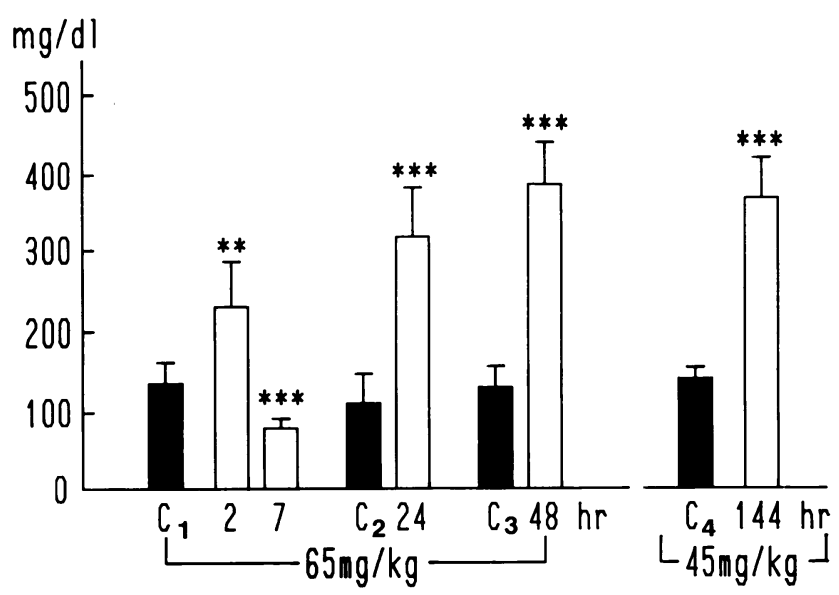

Fig. 2. Changes in plasma glucose levels after streptozotocin (STZ) injection in rats.

Plasma glucose levels were determined using commercial kits. Each animal was fasted for $18 \mathrm{hr}$ before intravenous STZ injection $(\square: 65 \mathrm{mg} / \mathrm{kg}$ or $45 \mathrm{mg} / \mathrm{kg}$ in $0.05 \mathrm{M}$ citrate buffer, $\mathrm{pH} 4.5$ ). Control rats $\left(\square, \mathrm{C}_{\mathrm{n}}: \mathrm{n}=1-4\right)$ received a corresponding volume of $0.05 \mathrm{M}$ citrate buffer and fasted for the same periods as STZ-treated rats. $\mathrm{C}_{1}$ : total fasting time is $18 \mathrm{hr}$. $\mathrm{C}_{2}$ : total fasting time is $42(18+24) \mathrm{hr} . \mathrm{C}_{3}$ : total fasting time is $66(18+48) \mathrm{hr}$. $\mathrm{C}_{4}$ : fasting time is $18 \mathrm{hr}$. Each point or column is mean \pm S.D. of 6 or 7 rats. $* *, * * *$ significant difference from the $C_{1}$ value with $\mathrm{p}<0.01, \mathrm{p}<0.001$, respectively. 
Table 1. Counts of various blood cells and hemoglobin $(\mathrm{Hb})$ and hematocrit ( $\mathrm{Ht})$ values after streptozotocin injection $(65$ or $45 \mathrm{mg} / \mathrm{kg}$ ) in rats.

\begin{tabular}{|c|c|c|c|}
\hline & Control & $\mathrm{STZ} 65 \mathrm{mg} / \mathrm{kg}, 48 \mathrm{hr}$ & $\mathrm{STZ} 45 \mathrm{mg} / \mathrm{kg}, 144 \mathrm{hr}$ \\
\hline PLA $\left(\times 10^{5} / \mu 1\right)$ & $10.00 \pm 1.39$ & $11.90 \pm 1.83 *$ & $8.75 \pm 1.71 \#$ \\
\hline WBC $\left(\times 10^{3} / \mu 1\right)$ & $6.38 \pm 1.14$ & $4.35 \pm 0.95 * *$ & $4.08 \pm 1.11^{* *}$ \\
\hline $\mathrm{RBC}\left(\times 10^{6} / \mu 1\right)$ & $7.25 \pm 0.58$ & $7.38 \pm 0.36$ & $7.83 \pm 0.24$ \\
\hline $\mathrm{Hb} \quad(\mathrm{g} / \mathrm{dl})$ & $14.80 \pm 0.77$ & $15.30 \pm 0.75$ & $15.60 \pm 0.64$ \\
\hline $\mathrm{Ht}(\%)$ & $42.20 \pm 3.80$ & $43.60 \pm 2.74$ & $47.50 \pm 1.29 * \#$ \\
\hline
\end{tabular}

PLA, platelet; WBC, white blood cell; $\mathrm{RBC}$, red blood cell; $\mathrm{Hb}$, hemoglobin; $\mathrm{Ht}$, hematocrit. At $48 \mathrm{hr}$ after $65 \mathrm{mg} / \mathrm{kg}$ and at $144 \mathrm{hr}$ after $45 \mathrm{mg} / \mathrm{kg}$ of STZ, blood specimens were collected after $18 \mathrm{hr}$ fasting. Control rats were sacrificed $48 \mathrm{hr}$ and $144 \mathrm{hr}$ after $0.05 \mathrm{M}$ citrate buffer treatment after fasting times of $18 \mathrm{hr}$. Each value is mean \pm S.D. of $6-8$ specimens. **, $*$ significant difference from the citrate buffer control value with $\mathrm{p}<0.01, \mathrm{p}<0.05$, respectively, \# significant difference from the value for $65 \mathrm{mg} / \mathrm{kg} \mathrm{STZ}$ treated rats with $\mathrm{p}<0.05$ (Student's $t$-test).

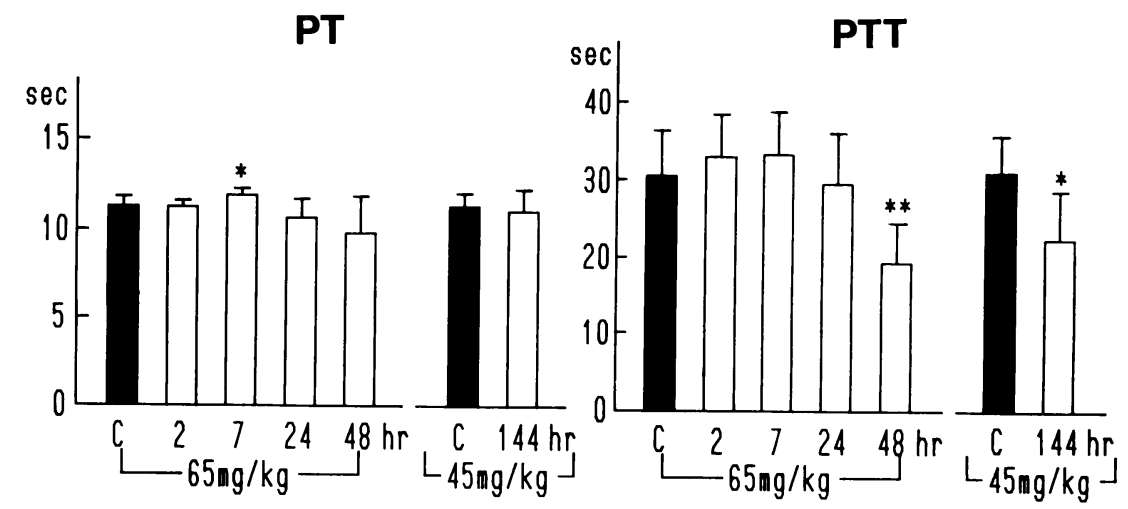

Fig. 3. Changes in PT and PTT in streptozotocin (STZ)-induced diabetic rats. PT and PTT were measured by using Simplastin and Platelin within $4 \mathrm{hr}$ after blood collection and each column shows sec. Each rat was fasted for $18 \mathrm{hr}$ after prefeeding for 5 days, and then received citrate buffer (C: $\square$ ) or STZ ( $\square: 65$ or $45 \mathrm{mg} / \mathrm{kg}$ in $0.05 \mathrm{M}$ citrate buffer) and the fasting time was from 18 to $66 \mathrm{hr}$. Each column is mean \pm S.D. of 6 or 7 rats. $*$, ** significant difference from the citrate buffer control value with $\mathrm{p}<0.05, \mathrm{p}<0.01$, respectively.

control rats. At $48 \mathrm{hr}$ and $144 \mathrm{hr}$ after STZ injection of $65 \mathrm{mg} / \mathrm{kg}$ and $45 \mathrm{mg} / \mathrm{kg}$, respectively, plasma glucose levels exceeded $250 \mathrm{mg} / \mathrm{dl}$. Table 1 shows the various values of blood parameters after STZ injection in rats. Platelet count increased $48 \mathrm{hr}$ after the treatment of $65 \mathrm{mg} / \mathrm{kg} \mathrm{STZ}$ and tended to decrease $144 \mathrm{hr}$ after $45 \mathrm{mg} / \mathrm{kg}$ injection of STZ. White blood cells decreased significantly after STZ treatment. Hematocrit values increased with a tendency for red blood cells to increase at $144 \mathrm{hr}$ after $45 \mathrm{mg} / \mathrm{kg}$ injection of STZ.

\section{$P T$ and PTT}

Figure 3 shows changes in PT and PTT in diabetic rats induced by STZ. In citrate control rats, we found no significant changes in PT or PTT due to the different fasting times. PT tended to be elongated $7 \mathrm{hr}$ after $65 \mathrm{mg} / \mathrm{kg}$ of STZ injection, whereas PTT was significantly shortened $48 \mathrm{hr}$ after $65 \mathrm{mg} / \mathrm{kg}$ treatment and $144 \mathrm{hr}$ after $45 \mathrm{mg} / \mathrm{kg}$. 

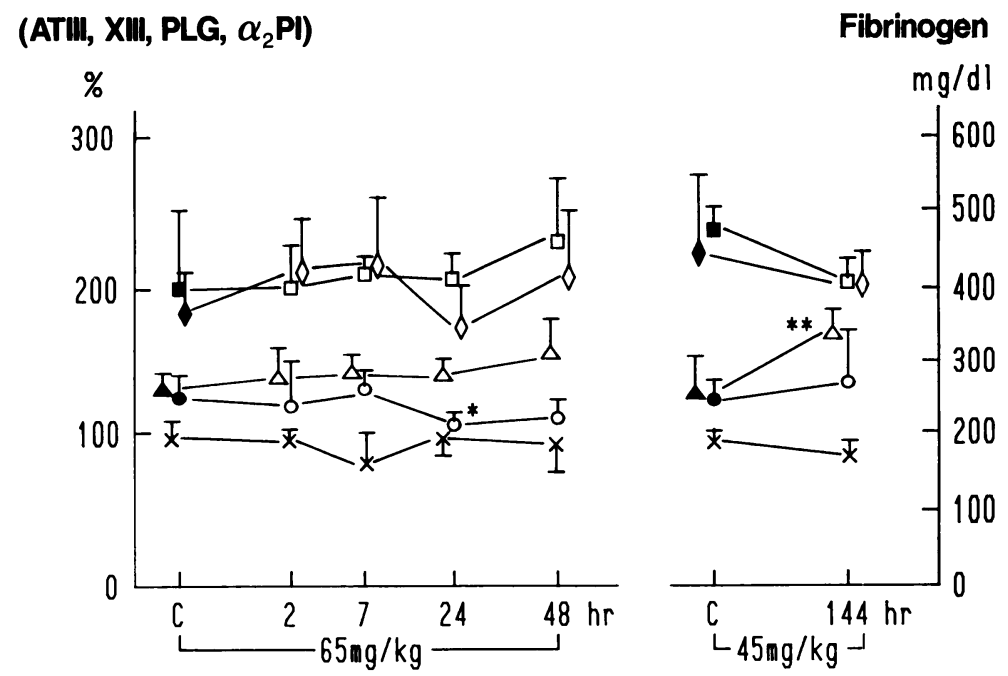

Fig. 4. Changes in the activity of coagulation and fibrinolytic factors in rats with streptozotocin-induced diabetes.

Fibrinogen (Fib: $\square-\square$ ) levels are shown in $\mathrm{mg} / \mathrm{dl}$, and the activity of factor XIII (XIII: - - ) is shown as intensity of dansylcadaverine complex fluorescence determined by a fluorescence spectrofluorometer. Plasminogen (PLG: $\diamond-\diamond$ ) content and activities of antithrombin III (ATIII: $\Delta-\Delta$ ) and $\alpha_{2}$-plasmin inhibitor $\left(\alpha_{2} \mathrm{PI}: X-X\right)$ are shown as ratios relative to normal human plasma. Each filled mark shows the control value. Each value is mean \pm S.D. of $6-8$ specimens. *, ** significant difference from the citrate buffer control value with $\mathrm{p}<0.05, \mathrm{p}<0.01$, respectively. For details, see Fig. 3.

\section{Fibrinogen, factor XIII, ATIII, PLG and $\alpha_{2}-P I$}

Figure 4 shows changes in the activity of coagulative and fibrinoytic factors in STZ-induced diabetes. In control rats, there were no significant effects of the different fasting times on fibrinogen level, factor XIII, or ATIII activity. No significant change in fibrinogen level was observed. The activity of factor XIII decreased $24 \mathrm{hr}$ after $65 \mathrm{mg} / \mathrm{kg}$ STZ injection. At $144 \mathrm{hr}$ after $45 \mathrm{mg} / \mathrm{kg} \mathrm{STZ}$, an apparent increase in ATIII activity was observed. We found no significant change induced by STZ in PLG content or $\alpha_{2}$-PI activity in acute diabetic rats. Plasma lipids

Figure 5 shows changes in TC, FC, TG, PL and NEFA contents in rat plasma. At 24 and $48 \mathrm{hr}$ after $65 \mathrm{mg} / \mathrm{kg} \mathrm{STZ}$ injection, TC and FC contents increased significantly. TG content was increased at 2, 7, 24 and $48 \mathrm{hr}$ after $65 \mathrm{mg} / \mathrm{kg} \mathrm{STZ}$ and $144 \mathrm{hr}$ after $45 \mathrm{mg} / \mathrm{kg}$ STZ injection. NEFA content increased apparently after $65 \mathrm{mg} / \mathrm{kg}$ STZ injection.

Relation between plasma glucose and PT, PTT and ATIII

Table 2 shows interrelations between the plasma glucose level and coagulative activity in STZ-induced diabetes. In control rats, no significant relation was found between the plasma glucose and coagulative activity. However, there was an interrelated shortening of PTT and an increase in ATIII activity with a remarkable increase in the plasma glucose level in STZinduced diabetic rats. 

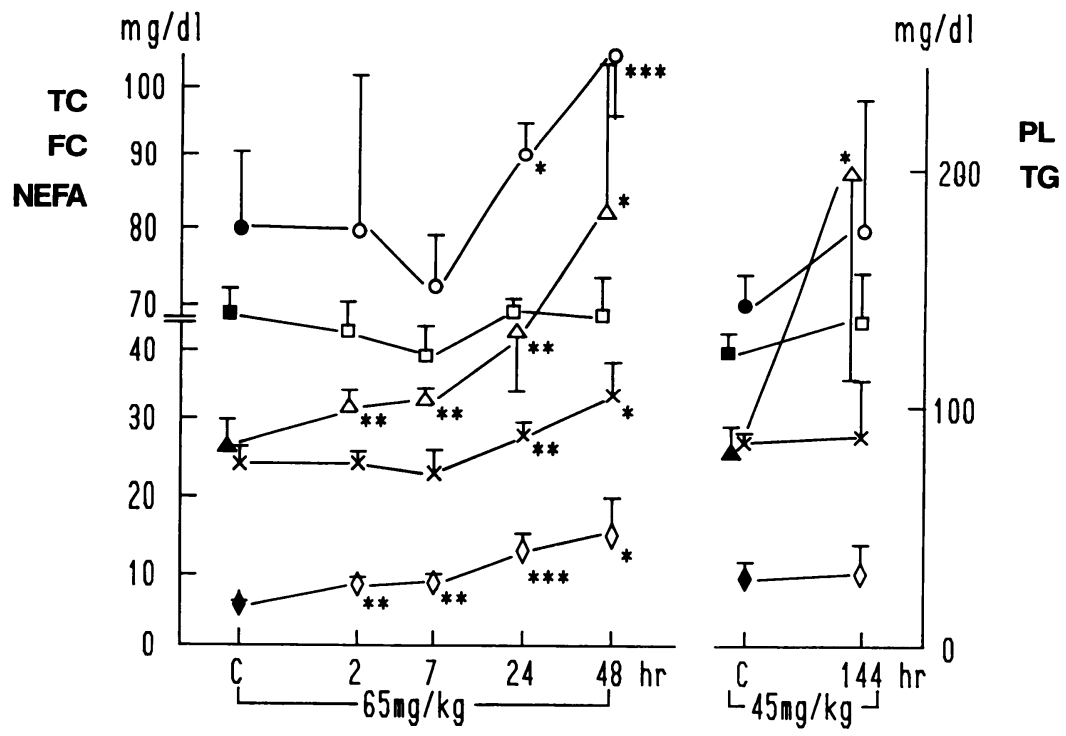

Fig. 5. Changes in plasma lipid levels in streptozotocin-treated rats.

Plasma lipid concentrations are shown in $\mathrm{mg} / \mathrm{dl}$, and each value is mean \pm S.D. of 6-8 specimens. *,**,*** significant difference from the control value with $\mathrm{p}<0.05$, $\mathrm{p}<0.001$, respectively. TC $(-\bigcirc)$ : total cholesterol, FC $(\times-\times)$ : free cholesterol, TG $(\Delta-\triangle)$ : triglyceride, PL $(\square-\square)$ : phospholipid, NEFA $(\diamond-\diamond)$ : non-esterified fatty acid. For details, see Fig. 3.

Table 2. Relation between plasma glucose and coagulation activity in streptozotocin (STZ)-induced diabetic rats.

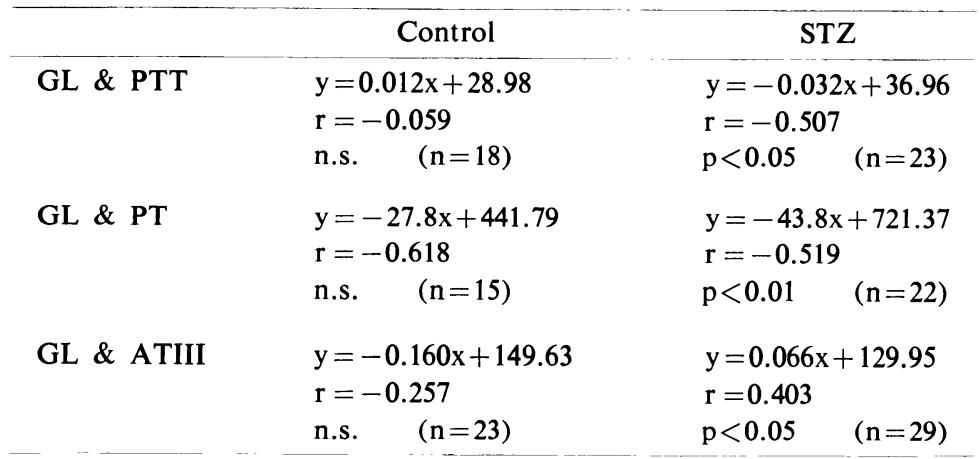

GL, plasma glucose; r, correlation coefficient.

\section{Discussion}

Diabetic patients have a higher incidence of micro- and macrovascular abnormalities associated with functional aberrations of the coagulation system ${ }^{14)}$, platelet aggregation ${ }^{15-17)}$ and prostaglandin metabolism ${ }^{16,17)}$. In the present paper, we demonstrated the shortening of PTT in STZ-induced diabetic rats. Considering that PTT is a test for factors included in the intrinsic system except platelet factor III, these acute diabetic rats showed enhancement of 
intrinsic coagulation. In addition, the PTT shortening was related significantly to the increase in plasma glucose in this experimental diabetic model.

STZ has been shown to be a selective B-cell toxin ${ }^{(6)}$. In the present study, treatment of rats with $65 \mathrm{mg} / \mathrm{kg}$ of STZ induced triphasic plasma glucose change, that is, an increase in plasma glucose after $2 \mathrm{hr}$, a decrease after $7 \mathrm{hr}$, and an increase after 24 and $48 \mathrm{hr}$. These changes were, respectively, induced by the suppression of insulin release, by the temporary increase in insulin release owing to the destruction of B-cells, and by the decrease in insulin release $^{())}$. Additionally, a single injection of $45 \mathrm{mg} / \mathrm{kg}$ of STZ to rats drastically increased food and water consumption without increasing body weight gain. These are the most typical symptoms of diabetes.

From the epidemiologic research, diabetes is associated with higher levels of the atherogenic risk factors, including hyperfibrinogemia, hypertension, hypertriglyceridemia and obesity ${ }^{18)}$. Fibrinogen concentration was significantly higher in diabetics than in non-diabetics, and a small but significant correlation was found between fibrinogen concentrations and plasma cholesterol concentrations ${ }^{19)}$. In our experiments, no increase in fibrinogen levels was observed, but we did observe that plasma from STZ-treated rats tended to form fibrin clots easily during the determination of fibrinogen content. We speculate that fibrinogen in the plasma had been consumed to form clots in acute diabetic rats before determination of fibrinogen levels. Simultaneously, indirect suppression of the hypercoagulation was suggested by the increase in ATIII activity and decrease in factor XIII activity. We found a decrease in factor XIII activity $24 \mathrm{hr}$ after injection of $65 \mathrm{mg} / \mathrm{kg}$ of STZ. This tendency may be a result of physiological reaction to counterbalance the enhancement and the suppression of coagulation. Our results indicated that the STZ treatment of rats induced enhancement of intrinsic coagulation demonstrated by the shortening of PTT. Significant relations between high plasma glucose levels and PTT shortening were also observed. The enhancement of intrinsic coagulation is considered to accompany activation of the kinin-kallikrein system, so it increases vascular permeability ${ }^{20)}$. From our results with the acute diabetic model, a high plasma level of glucose can be considered to trigger thrombosis. In addition, the subchronic diabetic rats also showed PTT shortening, which meant the enhancement of intrinsic coagulation (M. Okazaki et al., unpublished data). These changes in acute and subchronic diabetes will contribute to the development of atherosclerosis.

We observed no significant changes in fibrinolytic activity in rats with STZ-induced diabetes. Almer and Nilsson showed that the fibrinolytic defense system is impaired in diabetes, and they suggested that fibrin deposits that had not been removed contributed to the development of vascular lesions ${ }^{21}$. A more recent report also revealed that fibrinogen produced concentration-dependent inhibition of plasmin activity ${ }^{22}$ in an acute diabetic model in which the rats retained their fibrinolytic activity. It is interesting to examine the long-term effects of high plasma glucose level on fibrinolysis using a chronic diabetic model.

Examination of the blood of STZ-treated rats revealed an increase in the platelet count $48 \mathrm{hr}$ after $65 \mathrm{mg} / \mathrm{kg}$ of STZ and a tendency to decrease $144 \mathrm{hr}$ after $45 \mathrm{mg} / \mathrm{kg}$ of STZ. This suggests that treatment with a high dose of STZ can induce thrombosis. However, the prolonged high blood glucose level had the opposite tendency. One reason for this could be that platelets might be consumed in the process of coagulation. White blood cells were decreased in both diabetic rat models, which may be direct effects of STZ, because cells incubated in vitro with STZ contained numerous chromosomal abnormalities indicative of DNA 
strand breakage ${ }^{2: 3}$. On the other hand, non-enzymatic glucosylation of protein was increased due to the prolonged high blood glucose. Suzuki et al. ${ }^{24)}$ reported that the polymerization and cross linking of fibrin monomer were accelerated in the glucosylated fibrinogen. In addition, fibrinolysis by plasmin was delayed in fibrin formed from the glucosylated fibrinogen. That is, the glucosylation of plasma fibrinogen in diabetic patients may induce some different effects on blood coagulation and fibrinolysis.

Diabetes mellitus is often associated with lipid abnormalities. Recent experiments showed that serum cholesterol and triglyceride concentrations were significantly elevated at 1 and 6 months after induction of diabetes by a single injection of $65 \mathrm{mg} / \mathrm{kg} \mathrm{STZ}^{25)}$. In the present paper in rats with acute diabetes, we also demonstrated significant increases in total cholesterol, free cholesterol, triglyceride and non-esterified fatty acid 24 and $48 \mathrm{hr}$ after the injection of $65 \mathrm{mg} / \mathrm{kg} \mathrm{STZ}$. Since STZ induced decreased bile flow, bile acids output and BSP biliary excretion ${ }^{26)}$, one of explanation for the abnormal lipid metabolism might be the transient toxic effects of STZ on hepatocytes. In our previous paper, an increased fibrinogen level accompanied by increased plasma lipids was evident in triton WR-1339-induced hyperlipidemic rats $^{\tau)}$. In the present acute diabetic model, we could not demonstrate significance in the relation between the plasma lipids and fibrinogen level, and no relation between plasma fibrinogen and glucose levels was found. However, there was a positive relation between the shortening of PTT and the increase in plasma lipids in the STZ-induced diabetic model (data not shown). From these data, it could not be determined whether the increase in glucose level or lipid level enhanced the activity of the intrinsic coagulation in the acute diabetic rats. But changes in the coagulation system might be secondaly results of changes in plasma glucose.

In conclusion, STZ-induced acute diabetes showed an increase in plasma lipids and enhancement of intrinsic coagulation. Both were considered to induce trigger and/or promotion of atherosclerosis. These data further suggest that alteration of coagulative activity is important in the pathogenesis of atherosclerosis.

\section{References}

1) Laakso $\mathbf{M}$ and Pyörälä K: Lipid and lipoprotein abnormalities in diabetic patients with peripheral vascular disease. Atherosclerosis, 74: 55-63 (1988)

2) Mustard JF and Packham MA: Platelets and diabetes mellitus. N Engl J Med, 311: 665-667 (1984)

3) Silberbauer K, Schernthaner G, Sinzinger $\mathbf{H}$ and Freyler $\mathbf{H}$ : Platelet aggregation and reversible platelet aggregates in Type I-diabetes staged by retinal fluorescein angiography. Atherosclerosis, 40: 81-90 (1981)

4) Garćia Frade LJ, de la Calle H, Alava I, Navarro JL, Creighton LJ and Gaffney PJ: Diabetes mellitus as a hypercoagulable state: Its relationship with fibrin fragments and vascular damage. Thromb Res, 47: 533-540 (1987)

5) Herr RR, Jahnke HK and Argoudelis AD: The structure of streptozotocin. J Am Chem Soc, 89: 4808-4809 (1967)

6) Junod A, Lambert AE, Stauffacher $W$ and Renold AE: Diabetogenic action of streptozotocin: Relationship of dose to metabolic response. J Clin Invest, 48: 2129-2139 (1969)

7) Okazaki M, Suzuki S and Oguchi K: Changes in coagulative and fibrinolytic activities in Triton WR-1339-induced hyperlipidemia in rats. Jpn J Pharmacol, 52: 353-361 (1990)

8) Bragdon $\mathrm{JH}$ : Method for determination of total serum lipids. In: Lipids and Steroid Hormones in Clinical Medicine, Sunderman FW (ED), Lippincott, Philadelphia and Montreal, pp 9-14 (1960)

9) Duncombe WG: The colorimetric micro-determination of non-esterified fatty acids in plasma. Clin Chim Acta, 9: 122-125 (1964)

10) Langdell RD, Wagner RH and Brinkhous KM: Effect of antihemophilic factor on one-stage clotting 
tests. A presumptive test for hemophilia and a simple one-stage anti-hemophilic factor assay procedure. J Lab Clin Med, 41: 637-647 (1953)

11) Tomikawa $\mathbf{M}$, Ogawa $\mathbf{H}$ and Abiko $\mathbf{Y}$ : Experimental model of pulmonary thrombosis in rat. Thromb Diath Haemorrh, 31: 86-102 (1974)

12) Lowry $\mathrm{OH}$, Rosebrough NJ, Farr AL and Randall RJ: Protein measurement with the Folin phenol reagent. J Biol Chem, 193: 265-275 (1951)

13) Sugie I, Saeda $Y$ and Yamamoto $H$ : The studies of activation mechanism of fibrinolysis using by chromogenic substrates. Blood and Vessel, 11: 483-486 (1980) (in Japanese)

14) Jones RL and Peterson CM: Hematologic alterations in diabetes mellitus. Am J Med, 70: 339352 (1981)

15) Colwell JA, Halushka PV, Sarji K, Levine J, Sagel J and Nair RMG: Altered platelet function in diabetes mellitus. Diabetes, 25: 826-831 (1976)

16) Butkus A, Skrinska VA and Schumacher OP: Thromboxane production and platelet aggregation in diabetic subjects with clinical complications. Thromb Res, 19: 211-223 (1980)

17) Eldor A, Merin S and Bar-On H: The effect of streptozotocin diabetes on platelet function in rats. Thromb Res, 13: 703-714 (1978)

18) Nukada H: Increased susceptibility to ischemic damage in streptozotocin-diabetic nerve. Diabetes, 35: $1058-1061$ (1986)

19) Kannel WB, D'Agostino RB, Wilson PWF, Belanger AJ and Gagnon DR: Diabetes, fibrinogen, and risk of cardiovascular disease: The framingham experience. Am Heart J, 120: 662-676 (1990)

20) Matsuda $T$ and Yamanouchi $H$ : Problems about thrombogenic hypothesis of atherogenesis-Relationship between coagulability of blood or hematocrit values and grade of atherosclerosis. Atherosclerosis, 9: 543-549 (1981)

21) Almér L-O and Nilsson IM: On fibrinolysis in diabetes mellitus. Acta Med Scand, 198: 101-106 (1975)

22) Higazi AA and Mayer M: Inhibition of plasmin by fibrinogen. Biochem J, 269: 299-302 (1990)

23) Gaulton GN, Schwartz JL and Eardley DD: Assessment of the diabetogenic drugs alloxan and streptozotocin as models for the study of immune defects in diabetic mice. Diabetologia, 28: 769-775 (1985)

24) Suzuki S, Kanayama $\mathbf{M}$ and Yamanaka $\mathbf{M}$ : Alteration in coagulation and fibrinolytic activities of glycated fibrinogen from diabetic patients and inhibitory effect of drugs on glycation of fibrinogen. Blood and Vessel, 19: 605-611 (1988) (in Japanese)

25) Patel BN, Mackness MI, Harty DW, Arrol S, Boot-Handford, RP and Durrington PN: Serum esterase activities and hyperlipidaemia in the streptozotocin-diabetic rat. Biochim Biophys Acta, 1035: $113-116$ (1990)

26) Carnovale CE and Rodriguez Garay EA: Reversible impairment of hepatobiliary function induced by streptozotocin in the rat. Experientia, 40: 248-250 (1984)

[Received December 16, 1991: Accepted January 8, 1992] 